\title{
Afrique du nord, Moyen-Orient
}

\section{(2) OpenEdition \\ 12 Journals}

Édition électronique

URL : http://journals.openedition.org/transcontinentales/1490

DOI : 10.4000/transcontinentales. 1490

ISBN : 978-2-8218-1408-0

ISSN : 1775-397X

\section{Éditeur}

Editions de la maison des sciences de l'homme

\section{Édition imprimée}

Date de publication : 30 juin 2006

Pagination : 188

ISBN : 2200-92169-1

ISSN : $1950-1684$

\section{Référence électronique}

"Afrique du nord, Moyen-Orient », Transcontinentales [En ligne], 2 | 2006, document 25, mis en ligne le 15 décembre 2012, consulté le 25 septembre 2020. URL : http://journals.openedition.org/ transcontinentales/1490; DOI : https://doi.org/10.4000/transcontinentales.1490

Ce document a été généré automatiquement le 25 septembre 2020.

Tous droits réservés 


\section{Afrique du nord, Moyen-Orient}

1 Images d'Égypte. De la fresque à la bande dessinée, Le Caire, CÉDÉJ, 1991, 312 p.

2 PLANel Anne-Marie (dir.), Maghreb, dimensions de la complexité. Études choisies de l'IRMC (1992-2003), Tunis, IRMC (hors série Alfa. Maghreb et sciences sociales), 2004, $372 \mathrm{p}$.

3 BoISSIÈRE Thierry, Le jardinier et le citadin. Ethnologie d'un espace agricole urbain dans la vallée de l'Oronte en Syrie, Damas, IFPO, 2005, 471 p.

4 BOUTALEB A., J.-N. FERRIÉ et B. REY (coord.), L'autoritarisme dans le monde arabe. Autour de Michel Camau - Luis Martinez, Le Caire, CÉDÉJ, juin 2005, 107 p. 